\title{
An update on the genetic causes of central precocious puberty
}

\author{
Young-Lim Shin, MD, PhD \\ Department of Pediatrics, \\ Soonchunhyang University \\ Bucheon Hospital, Soonchunhyang \\ University College of Medicine, \\ Bucheon, Korea
}

Central precocious puberty (CPP) is caused by the premature reactivation of the hypothalamic-pituitary-gonadal axis. Genetic, nutritional, and environmental factors play a crucial role in determining pubertal timing. Recently mutations in kisspeptin (KISS1), kisspeptin receptor (KISS1R), and makorin RING finger protein 3 (MKRN3) genes have been identified as genetic causes of CPP. In particular, the $M K R N 3$ gene is known to affect pubertal initiation. The MKRN3 gene is located on chromosome 15q11-q13 in the Prader-Willi syndrome (PWS) critical region. MKRN3 deficiency, due to a loss of function mutation, leads to the withdrawal of hypothalamic inhibition and prompts pulsatile gonadotropin-releasing hormone secretion, resulting in precocious puberty. The exact functions of these genes associated with CPP are still not well understood. Larger studies are required to discover the mechanisms involved in pubertal development.

Keywords: Central precocious puberty, Kisspeptins, MKRN3 gene, Mutation

\section{Introduction}

Gonadotropin-releasing hormone $(\mathrm{GnRH})$ secretion is active in infancy and then becomes quiescent in childhood. At the onset of puberty, the reactivation of pulsatile GnRH secretion leads to an increase in the secretion of the gonadotropins and consequent gonadal stimulation ${ }^{1)}$. Central precocious puberty (CPP) is caused by the premature reactivation of the hypothalamic-pituitary-gonadal axis and is usually defined by the development of secondary sexual characteristics before the age of 8 in girls and 9 in boys ${ }^{2,3)}$.

Complex interactions with genetic, nutritional and environmental factors play a crucial role in determining pubertal timing ${ }^{4)}$. Genetic factors are have been considered to have a strong influence on pubertal initiation ${ }^{5}$. CPP is usually regarded to be idiopathic. de Vries et al. ${ }^{6}$ mentioned that familial cases accounted for $27.5 \%$ (43 out of 156 children) of CPP, and segregation analysis suggested an autosomal dominant transmission with incomplete sexdependent penetrance.

Numerous studies have been conducted to explore the genetic causes for CPP. The GABRA1, NPY-Y1R, LIN28B, TAC3 and TACR3 genes were considered regarded as potential the cause of $\mathrm{CPP}$, but no mutations associated with CPP were found in these genes ${ }^{7-10)}$. Recently, kisspeptin (KISS1), kisspeptin receptor (KISS1R), and makorin RING finger protein 3 (MKRN3) genes were found to be responsible for CPP, but a few cases of CPP with these mutations have been reported to date $\mathrm{e}^{11-13)}$.

\footnotetext{
Address for correspondence: Young-Lim Shin, MD, PhD

Department of Pediatrics, Soonchunhyang University Bucheon Hospital, Soonchunhyang University College of Medicine, 170 Jomaru-ro, Wonmi-gu, Bucheon 14584, Korea Tel: +82-32-621-5407 Fax: +82-32-621-5016 E-mail:ylshin@schmc.ac.kr
}

\section{KISS1 and KISS1R gene}

Kisspeptin and its receptor have been considered essential components in pubertal onset. KISS1 encodes kisspeptin, which is a natural ligand that binds to the KiSS-1 receptor (KISS1R), a G-protein coupled receptor ${ }^{14)}$. Several studies have demonstrated that loss of 
function mutations in KISS $1 R$ were detected in idiopathic hypogonadotropic hypogonadism patients and it was suggested that this receptor is a regulator of GnRH secretion ${ }^{15,16)}$. Kisspeptin is shown to activate hypothalamic GnRH secretion, after binding KISS1R in hypothalamic GnRH-neurons ${ }^{14)}$. KISS1 and KISS1R expressions are increase at the onset of puberty ${ }^{14)}$.

In 2008, Teles et al. ${ }^{11)}$ detected a gain-of-function mutation in the KISS1R gene in a girl with CPP. They identified an autosomal dominant p.Arg386Pro mutation. This mutation prolongs the activation of kisspeptin responsive to intracellular signaling and reduces the rate of normal KISS1R desensitization ${ }^{11)}$. In response to kisspeptin stimulation, pulsatile of $\mathrm{GnRH}$ secretion increases and induces the initiation of puberty ${ }^{17)}$. Silveira et al. ${ }^{12)}$ reported the p.P74S mutation in KISS1 gene in a boy with very early pubertal development at 12 months of age, and suggested this mutation was associated with higher kisspeptin resistance to degradation, leading to an increased availability of bioactive kisspeptin. However, so far, KISS1 and KISS1R mutation have been very rarely found in patients with $\mathrm{CPP}^{18)}$.

\section{MKRN3 gene}

In 2013, through whole-exome sequencing analysis, Abreu et al. ${ }^{13)}$ detected $M K R N 3$ gene mutations in 5 of 15 families with CPP. They found that three frameshift mutations (Arg213Glyfs ${ }^{\star} 73, \operatorname{Tyr} 31^{\star}$, and Ala162Glyfs ${ }^{\star} 14$ ) were predicted to encode truncated proteins and one missense mutation (Arg365Ser) predicted to disrupt protein function in 5 families originated from North America, Brazil, and Belgium.

The MKRN3 gene is located on chromosome 15q11-q13 in the Prader-Willi syndrome (PWS) critical region ${ }^{19)}$. While studying a PWS critical region in 1999, Jong et al. ${ }^{19)}$ discovered $M K R N 3$ gene. This gene is methylated on the maternal allele, but is unmethylated on the paternal allele. Therefore, the maternal imprinted MKRN3 gene is expressed only from the paternal allele and si silenced from the maternal allele. All affected patients with familial CPP inherited the MKRN3 mutations from their father ${ }^{19)}$. PWS patients usually have delayed or incomplete puberty despite MKRN3 gene deletion. However, rare cases with CPP in PWS have been reported ${ }^{20,21}$. There is a needs to evaluate genetic factors in 15q11-13 PWS critical region as related to pubertal timing.

The MKRN3 protein has $2 \mathrm{~N}$-terminal $\mathrm{C} 3 \mathrm{H}$ zinc finger motifs, 1 MKRN specific Cys-His domain, 1 C3HC4 RING zinc finger motif, and $1 \mathrm{C}$-terminal $\mathrm{C} 3 \mathrm{H}$ zinc finger motif ${ }^{19)}$. Until now, 21 MKRN3 mutations have been described including 8 frameshift mutations, 10 missense mutations and 3 nonsense mutations $^{13,22-29)}$ (Fig. 1). Abreu et al. ${ }^{13)}$ suggested that the function of $M K R N 3$ gene relevant to pubertal initiation include an inhibiting effect on the pubertal pulsatile GnRH secretion. Their study showed that hypothalamic Mkrn3 mRNA levels were increased in the arcuate nucleus of male and female mice at a young age and decreased immediately before puberty. They suggested they mentioned the Mkrn3 mRNA expression pattern is associated with an inhibitory effect on onset of puberty. Ojeda and Lomniczi ${ }^{30)}$ also suggested that MKRN3 inhibits the downstream activators of hypothalamic GnRH secretion, such as KISS1. MKRN3 deficiency due to a loss of function mutation leads to the withdrawal of hypothalamic inhibition, which releases and pulsatile GnRH secretion, and therefore precipitates the early onset of puberty ${ }^{22)}$. In a study by Hagen et al. $^{31)}$, the authors ascertained undetectable or low MKRN3 levels in patients with early onset of puberty, and MKRN3 levels were negatively correlated with gonadotropins in serum from prepubertal girls.

Settas et al. ${ }^{22)}$ demonstrated that a novel heterozygous missense MKRN3 mutation (p.Cys340Gly) detected in 2 affected Greek sibling. The p.Cys340Gly mutation was predicted to disrupt the protein function in silico analysis. These 2 patients, a girl with CPP and a boy with early puberty, had inherited the mutated $M K R N 3$ gene from their asymptomatic carrier father and paternal grandmother. Macedo et al. ${ }^{23)}$ reported

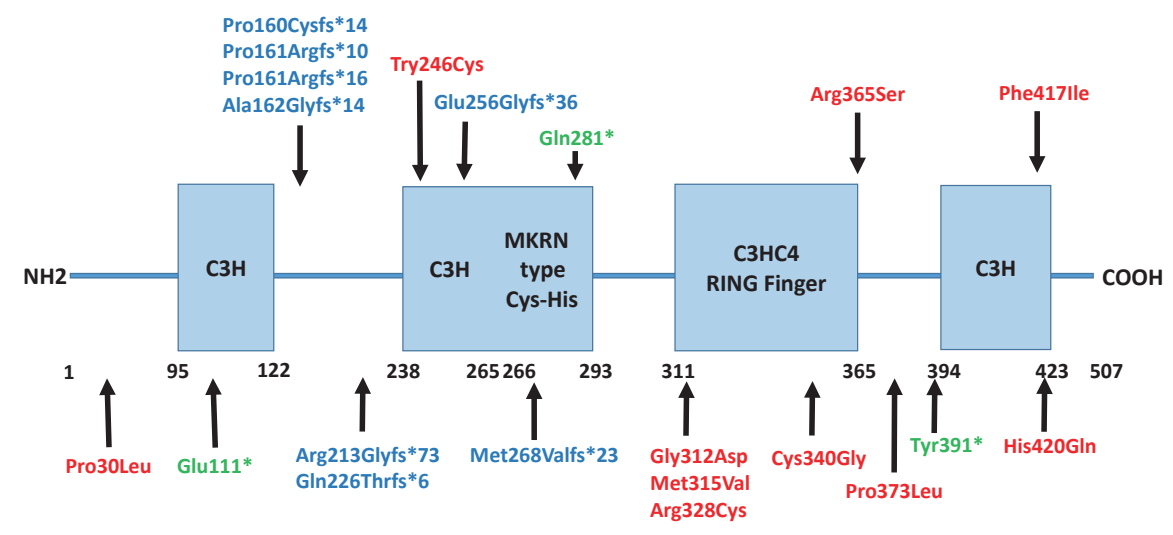

Fig. 1. MKRN3 domains (3 C3H zinc finger motifs, 1 C3HC4 RING zinc finger motif, and 1 MKRN specific Cys-His domain) and MKRN3 mutations identified in patients with central precocious puberty. The numbers correspond to the amino acid positions in the protein. 8 frameshift mutations (blue), 10 missense mutations (red) and 3 nonsense mutations (green) are shown. 
five novel heterozygous mutations in eight unrelated Brazilian patients with sporadic CPP. These mutations were composed of 4 frameshift mutations, predicted to encode truncated proteins, and 1 missense mutation (p.Phe417lle), which were all informed of paternally inheritance in segregation analysis. de Vries et $\mathrm{al}^{24)}$ identified a novel missense mutation (p.His420Gln) predicted to disturb RNA binding in the MKRN3 gene. Schreiner et al. ${ }^{25)}$ identified 2 heterozygous mutations (a previous reported variant, p.Ala162Glyfs ${ }^{*} 14$ and a novel mutation, p.Glu111 ${ }^{\star}$ ) in the MKRN3 gene in 2 German families with CPP.

All patients with loss of function mutations in $M K R N 3$ gene show have typical clinical and hormonal finding of CPP, including breast or testicular enlargement, advanced bone age, accelerated growth velocity, and stimulated luteinizing hormone levels elevation ${ }^{13,22,23)}$. Very few patients with MKRN3 mutations had mild syndromic features. Two related patients had esotropia ${ }^{13)}$ and a girl had mild nonspecific features, including a high arched palate, clinodactyly, dental abnormalities and hyperlordosis ${ }^{23}$. Apart from these, no other signs were evident in CPP patients with $M K R N 3$ mutations including features of PWS ${ }^{13,23)}$. MKRN3 mutations affect both genders equally but seem to affect girls more severely in the onset age for puberty ${ }^{13,22}$. The reason for this gender difference is not yet clear. Between CPP patients with MKRN3 mutation and those without $M K R N 3$ mutation, the age of pubertal initiation does not differ significantly ${ }^{23}$. However, another study has reported the girls with MKRN3 mutations are significantly younger at puberty onset than those without mutations ${ }^{27)}$. Response to treatment with depot GnRH agonists are good in CPP patients with MKRN3 defects ${ }^{13,23,27)}$.

\section{Conclusions}

Pubertal timing is determined by interaction between inhibitory effects and stimulatory effects of hypothalamicpituitary-gonadal axis. It is generally accepted that the MKRN3 gene is the most frequently known genetic cause of pubertal initiation. However, the exact mechanism involved in pubertal development are still not well understood. Larger studies on the clinical features of CPP patients with MKRN3 mutations are required and an ongoing effort to find other factors associated with the puberty should be maintained.

\section{Conflict of interest}

No potential conflict of interest relevant to this article was reported.

\section{References}

1. Terasawa E, Fernandez DL. Neurobiological mechanisms of the onset of puberty in primates. Endocr Rev 2001;22:11151 .

2. Partsch CJ, Heger S, Sippell WG. Management and outcome of central precocious puberty. Clin Endocrinol (Oxf) 2002;56:129-48.

3. Carel JC, Leger J. Clinical practice: precocious puberty. N Engl J Med 2008;358:2366-77.

4. Gajdos ZK, Hirschhorn JN, Palmert MR. What controls the timing of puberty? An update on progress from genetic investigation. Curr Opin Endocrinol Diabetes Obes 2009;16:16-24.

5. Palmert MR, Boepple PA. Variation in the timing of puberty: clinical spectrum and genetic investigation. J Clin Endocrinol Metab 2001;86:2364-8.

6. de Vries L, Kauschansky A, Shohat M, Phillip M. Familial central precocious puberty suggests autosomal dominant inheritance. J Clin Endocrinol Metab 2004;89:1794-800.

7. Brito VN, Mendonca BB, Guilhoto LM, Freitas KC, Arnhold IJ, Latronico AC. Allelic variants of the gamma-aminobutyric acid-A receptor alphal-subunit gene (GABRA1) are not associated with idiopathic gonadotropin-dependent precocious puberty in girls with and without electroencephalographic abnormalities. J Clin Endocrinol Metab 2006;91:2432-6.

8. Freitas KC, Ryan G, Brito VN, Tao YX, Costa EM, Mendonca BB, et al. Molecular analysis of the neuropeptide Y1 receptor gene in human idiopathic gonadotropindependent precocious puberty and isolated hypogonadotropic hypogonadism. Fertil Steril 2007;87:627-34.

9. Silveira-Neto AP, Leal LF, Emerman AB, Henderson KD, Piskounova E, Henderson BE, et al. Absence of functional LIN28B mutations in a large cohort of patients with idiopathic central precocious puberty. Horm Res Paediatr 2012;78:144-50.

10. Tusset C, Noel SD, Trarbach EB, Silveira LF, Jorge AA, Brito $\mathrm{VN}$, et al. Mutational analysis of TAC3 and TACR3 genes in patients with idiopathic central pubertal disorders. Arq Bras Endocrinol Metabol 2012;56:646-52.

11. Teles MG, Bianco SD, Brito VN, Trarbach EB, Kuohung W, $\mathrm{Xu}$ S, et al. A GPR54-activating mutation in a patient with central precocious puberty. N Engl J Med 2008;358:709-15.

12. Silveira LG, Noel SD, Silveira-Neto AP, Abreu AP, Brito VN, Santos MG, et al. Mutations of the KISS1 gene in disorders of puberty. J Clin Endocrinol Metab 2010;95:2276-80.

13. Abreu AP, Dauber A, Macedo DB, Noel SD, Brito VN, Gill JC, et al. Central precocious puberty caused by mutations in the imprinted gene MKRN3. N Engl J Med 2013;368:246775 .

14. Navarro VM, Castellano JM, Garcia-Galiano D, TenaSempere M. Neuroendocrine factors in the initiation of puberty: the emergent role of kisspeptin. Rev Endocr Metab Disord 2007;8:11-20.

15. Seminara SB, Messager S, Chatzidaki EE, Thresher RR, Acierno JS Jr, Shagoury JK, et al. The GPR54 gene as a regulator of puberty. N Engl J Med 2003;349:1614-27.

16. de Roux N, Genin E, Carel JC, Matsuda F, Chaussain JL, Milgrom E. Hypogonadotropic hypogonadism due to loss of function of the KiSS1-derived peptide receptor GPR54. 
Proc Natl Acad Sci U S A 2003;100:10972-6.

17. Bianco SD, Vandepas L, Correa-Medina M, Gereben B, Mukherjee A, Kuohung W, et al. KISS1R intracellular trafficking and degradation: effect of the Arg386Pro disease-associated mutation. Endocrinology 2011;152: 1616-26.

18. Leka-Emiri S, Louizou E, Kambouris M, Chrousos G, De Roux N, Kanaka-Gantenbein C. Absence of GPR54 and TACR3 mutations in sporadic cases of idiopathic central precocious puberty. Horm Res Paediatr 2014;81:177-81.

19. Jong MT, Gray TA, Ji Y, Glenn CC, Saitoh S, Driscoll DJ, et al. A novel imprinted gene, encoding a RING zincfinger protein, and overlapping antisense transcript in the Prader-Willi syndrome critical region. Hum Mol Genet 1999;8:783-93.

20. Crino A, Di Giorgio G, Schiaffini R, Fierabracci A, Spera S, Maggioni A, et al. Central precocious puberty and growth hormone deficiency in a boy with Prader-Willi syndrome. Eur J Pediatr 2008;167:1455-8.

21. Lee HS, Hwang JS. Central precocious puberty in a girl with Prader-Willi syndrome. J Pediatr Endocrinol Metab 2013;26:1201-4.

22. Settas N, Dacou-Voutetakis C, Karantza M, KanakaGantenbein C, Chrousos GP, Voutetakis A. Central precocious puberty in a girl and early puberty in her brother caused by a novel mutation in the MKRN3 gene. J Clin Endocrinol Metab 2014;99:E647-51.

23. Macedo DB, Abreu AP, Reis AC, Montenegro LR, Dauber A, Beneduzzi D, et al. Central precocious puberty that appears to be sporadic caused by paternally inherited mutations in the imprinted gene makorin ring finger 3. J Clin Endocrinol
Metab 2014;99:E1097-103.

24. de Vries L, Gat-Yablonski G, Dror N, Singer A, Phillip M. A novel MKRN3 missense mutation causing familial precocious puberty. Hum Reprod 2014;29:2838-43.

25. Schreiner F, Gohlke B, Hamm M, Korsch E, Woelfle J. MKRN3 mutations in familial central precocious puberty. Horm Res Paediatr 2014;82:122-6.

26. Grandone A, Cantelmi G, Cirillo G, Marzuillo P, Luongo C, Miraglia del Giudice E, et al. A case of familial central precocious puberty caused by a novel mutation in the makorin RING finger protein 3 gene. BMC Endocr Disord 2015;15:60.

27. Simon D, Ba I, Mekhail N, Ecosse E, Paulsen A, Zenaty D, et al. Mutations in the maternally imprinted gene MKRN3 are common in familial central precocious puberty. Eur J Endocrinol 2016;174:1-8.

28. Lee HS, Jin HS, Shim YS, Jeong HR, Kwon E, Choi V, et al. Low frequency of MKRN3 mutations in central precocious puberty among Korean girls. Horm Metab Res 2016;48:118-22.

29. Neocleous V, Shammas C, Phelan MM, Nicolaou S, Phylactou LA, Skordis N. In silico analysis of a novel MKRN3 missense mutation in familial central precocious puberty. Clin Endocrinol (Oxf) 2016;84:80-4.

30. Ojeda SR, Lomniczi A. Puberty in 2013: unravelling the mystery of puberty. Nat Rev Endocrinol 2014;10:67-9.

31. Hagen CP, Sørensen K, Mieritz MG, Johannsen TH, Almstrup K, Juul A. Circulating MKRN3 levels decline prior to pubertal onset and through puberty: a longitudinal study of healthy girls. J Clin Endocrinol Metab 2015;100:1920-6. 